\title{
Decision Support System for increasing position of Office at PT. Gramedia Asri Media using Profile Matching Method
}

\author{
Kartika Mariskhana $^{1)^{*}}$, Ita Dewi Sintawati ${ }^{2)}$, Widiarina ${ }^{3)}$, Rusdiansyah ${ }^{4)^{*}}$ \\ 1)23)4) Bina Sarana Informatics, Indonesia \\ ${ }^{1)}$ kartika.kma@bsi.ac.id, ${ }^{2)}$ ita.ids@bsi.ac.id, ${ }^{3}$ widiarina.wda@bsi.ac.id, ${ }^{4)}$ Rusdiansyah.rds@bsi.ac.id
}

Submitted : Feb 5, 2021 | Accepted : Mar 14, 2021 | Published : Apr 1, 2021

\begin{abstract}
The more rapid development of information technology in the world, many people take advantage of advances in information technology in various activities of life or to solve various problems. One of them is that filling in positions that have not been filled for the promotion process often experiences problems because the submission of candidates who can occupy that position by matching the employee profile and the job profile is not resolved properly. To minimize these constraints we need a decision support system that can analyze employee performance in accordance with existing job profiles. the criteria that are required for promotion at PT. Gramedia Asri Media is carried out in order to obtain accurate data. For promotion at PT. Gramedia Asri Media, required aspects that have been determined as a condition for determining a promotion. The following are the aspects that become these requirements obtained from research at PT. Gramedia Asri Media is a performance aspect and a behavior aspect. The application of the Profile Matching process is carried out to determine career planning recommendations by calculating sub-criteria for each aspect (performance attitudes and intellectual capacity) which consists of 4 stages, namely the calculation of the GAP value, the calculation of the value of the core and secondary factors and the calculation of the total value and ranking. The results of this study produce a form of recommendation for employees with the highest score which has the same numerical value as the method of calculating the amount used.
\end{abstract}

Keywords: Competent, Competitive, Credible, Employee performance, GAP value Profile Matching

\section{INTRODUCTION}

Human resources in a corporate organization are very important to support the progress and quality of the company in achieving its goals(Susan, 2019). Promotion is a very important factor for employee career planning(Abdullah, Djanggih, Suendri, Cipta, \& Nofriadi, 2018) and also for rejuvenating a position so that it is occupied by someone who has suitable criteria to occupy a proposed position(Sahya Anggara, 2016)

Promotion is one of the most important factors for employee career planning and also for rejuvenating a position so that it is occupied by someone who has suitable criteria to occupy a proposed position. The first criteria proposed, namely, work attitudes, and intelligence possessed by employees(Wong \& Law, 2017). The second criterion is education level, length of time working, work performance. With the subjective assessment(Pradnyawati \& Komalasari, 2017), it creates social jealousy towards employees who feel unfair to the prevailing decisions(Antonius \& Widjaja, 2019). The findings of the detected problems, including, there is still an unilateral assessment which causes social jealousy and the assessment is not objective or subjectivity in appraising employee performance which is almost inevitable(Antonius \& Widjaja, 2019).

PT. Gramedia Asri Media is a company that provides bookstore chains with the name Gramedia Bookstore in several cities in Indonesia. The company was founded on February 2, 1970, starting from a small bookstore measuring $25 \mathrm{~m}^{2}$ in the West Jakarta area and until 2002 it has grown to more than 50 well-known shops throughout Indonesia. The problems that occur at the time of promotion of promotion to employees, the research is focused on the HR division at PT. Gramedia Asri Media, the information obtained from the research includes the category of behavioral aspects, namely the value of caring, credibility, competence, competence, costomer deligt, each of which has a behavior value and the next step is to find a value of 3 points and a weight value of $\mathrm{X}$ as well. must 
be at least 5 points, then find the overall total score. After all the overall scores have been calculated and the results obtained, it will determine the selection for the promotion. Very Good category with a rating scale of 440-500, Exceeds expectations with a rating scale of 350-440, Fulfills Expectations with a rating scale of 250-350, Needs to improve with a rating scale of 160-250, Unacceptable with a rating scale of 160 . Of these companies will assess employees who will be promoted in the company, as long as all assessments are included in the Meet Expectation category if they do not reach the Meet Expectation, then the employee cannot take the promotion test (Sofiati, 2018).

\section{Decision Support System}

\section{LITERATURE REVIEW}

The concept of Decision Support Systems was first introduced in the early 1970's by Michael Scott Morton, hereinafter known as Management Decision Systems(Wati \& Mayasari, 2015). The concept of a Decision Support System is a computer-based interactive system that helps decision makers utilize data and models to solve unstructured and semi-structured problems(Ariyanto \& Muslihudin, 2015). The definition of a decision support system is a decision support system is an interactive system that supports decisions in the decision-making process through alternatives obtained from the results of data processing(Adianto, Arifin, Khairina, Mahakam, \& Palm, 2017), information and model design. Decision Support Systems are information-making systems aimed at a specific problem that must be solved by managers and can assist managers in decision making. Decision support systems are an integral part of the totality of the entire organizational system(Susanto, 2018).

The decision support system is a systematic approach to the essence of a problem, gathering mature determinants of the alternatives faced and taking the most appropriate action(Tinggiana, Y., Pujiastuti, A., 2018). A decision support system is a computer-based system that produces various alternative decisions to assist management in dealing with various structured or unstructured problems using data and models. To produce good decisions in a decision support system(Fitri, 2017), it needs to be supported by quality information and facts, among others:

1. Accessibility

This attribute is related to the ease of obtaining information, information will be more meaningful to the user if the information is easy to obtain, because it will be related to the activity of the information value.

2. Completeness

This attribute is related to the completeness of the content of the information, in this case the content is not only about volume but also conformity to the expectations of the user, so that this completeness is often difficult to measure quantitatively.

3. Accuracy

This attribute relates to the possible error rate in the execution of processing large amounts of data (volume).

Two types of errors that occur frequently are those related to calculations.

4. Accuracy

This attribute is related to the suitability of the information generated with the needs of the user. As with completeness, accuracy is very difficult to measure quantitatively.

5. Punctuality of Time

The quality of information is also largely determined by the timing of its delivery and actualization. For example, information related to daily planning would be very useful if it was submitted once every two days.

6. Clarity

This attribute relates to the form or format of delivering information. For a leader, information presented in the form of graphs, histograms, or pictures will usually be more meaningful than information in the form of long words.

7. Flexibility

This attribute relates to the degree of adaptation of the information generated to the needs of various decisions to be taken and to a group of different decision makers.

\section{Profile Matching Method}

In this research, quantitative research techniques are used with a descriptive type which is carried out by determining the following aspects: academic aspects, personality aspects, family economic aspects (average monthly income, dependents of parents, vehicles), after these aspects are determined, the method This will look for the GAP between the profile and the state of the data from the student(Junaidi \& Visella, 2017). This method determines the presentation of the two aspect elements and is totaled, then a ranking process is carried out which will determine the optimal alternative, namely students who deserve a scholarship(Junaidi \& Visella, 2017).

The Profile Matching method or profile matching is a method that is often used as a mechanism in decision making by assuming that there is an ideal predictor variable level that must be met by the subject under study, not a minimum level that must be met or passed(Akhirina, 2016). In the Profile Matching process, in general, it is a 
process of comparing the actual value of a profile to be assessed with the expected profile value, so that the difference in competence is 10 (also called the gap), the smaller the resulting gap, the greater the weight value which means it a greater chance is recommended to be selected in this case students who excel and deserve a scholarship(Nur Aziz Sugiharto, 2016). The calculation process in the Profile Matching method begins with defining the minimum value for each assessment variable. The difference between each value of the testing data and the minimum value of each variable is the gap which is then weighted(Nisa \& Sutinah, 2018).

a. Profile Matching Algorithm

Mapping the Competency Gap is the difference between a student's score profile and a scholarship profile or bias is indicated by equation(1)(Kay \& Kibble, 2016).

b. Gap = Student Score - Target Value.

Weighting After obtaining the gap for each object, each object's profile is given a weight based on the weight of the gap value(Tremblay et al., 2018).

c. Calculation and grouping of Core Factors and Secondary Factors. Core Factor calculations can be seen in the equation (2).

$\mathrm{NCF}=\frac{\sum N C(\text { kriteria })}{\sum I C}$

Information :

$\mathrm{NCF}$ : Average core factor values

NC : The total number of core factors

IC : The number of core factor items

Meanwhile, Secondary Factor are items other than those in the main factor (Core factor).

Secondary Factor using equations (3).

$N S F=\frac{\sum N S(\text { kriteria })}{\sum I S}$

Information :

NSF: Mean value of secondary factor

NS: The total number of secondary factors

IS: The number of secondary factor items Information :

d. Total Value Calculation

From the calculation of each aspect above, then the total value is calculated based on the percentage of the core factor and the secondary factor which is estimated to affect the performance of each profile. Calculations can be done using equations (4).

$(x) \% N C F+(x) \% N S F=N($ Total Aspect Criteria $)$

Information :

NCF: Average core factor values

NSF: Mean value of secondary factor

$\mathrm{N}$ : The total value of the aspects

(x)\%: The percent value entered Information :

e. Calculation of Rank Determination

The final result of the Profile Matching process is the ranking of candidates submitted to the scholarship recipients. Can be seen in the equation (5).

Rank $=(x) \% N a+(x) \% N K$.

Information :

$\mathrm{Na}$ : Academic Value

Nk: Personality Values

(x)\%: Input Value Percent Information :

\section{METHOD}

Contains research results. The research results can be supplemented with tables, graphs, or pictures. The discussion section describes the results of data processing, interpretation of the research results obtained, linking with appropriate reference sources(Susanti, 2020). The research method used in this research is quantitative descriptive method(Wati \& Mayasari, 2015). Some of the ease in using this method is because researchers in conducting research collect information and data needs from the research site based on the current situation as well as the information and data obtained as is. Furthermore, the researcher analyzes the matter so that the researcher knows the shortcomings of this, so that the researcher can improve by completing the shortcomings. Furthermore, 
in the research conducted, the researcher carried out an objective measurement of the eligibility process for promotion, so that the need for this needs to be translated into several problem components, variables and indicators(Akhirina, 2016). Each determined variable is measured by providing different numeric symbols according to the information category associated with that variable. By using these number symbols, quantitative mathematical calculation techniques can be carried out so as to produce a conclusion in the form of a final result that can be used as a recommendation for the Manager in the eligibility for promotion.

The Decision Making Process consists of 3 stages, namely as follows:

\section{Observation}

The method used to obtain data is by direct survey to the company of the object under study about how the process of promotion at PT. GRAMEDIA ASRI.

\section{Interview}

In retrieving data in this study was carried out by holding questions and answers directly to Ms. Henilan as Human Resources in order to obtain employee data, employee value data and employee weight values in accordance with this study.

\section{Literature study}

By collecting and studying literature related to the profile matching method and discussing promotion issues in the form of books and journals.

In this scientific research the authors use the profile matching method, and the following criteria aspects:

a. Employee Performance Aspects

b. Behavioral Aspects

c. Total Rating

The scale of the assessment with the score of each choice is as follows:

Table 1

Rating Scale Table

\begin{tabular}{cll}
\hline \hline Number & Category & Scoring scale \\
\hline 1 & Outsourcing & $>440-500$ \\
2 & Exceed Expection & $>350-440$ \\
3 & Meet Expectation & $>250-350$ \\
4 & Need Improvement & $>160-250$ \\
5 & Unacceptable & $>160$ \\
\hline
\end{tabular}

Determine the ratimg scale based on the categories which include; outsourcing, exceed expection, meet improvement, need improment and unacceptable. with the Socre scale above table 1.

Analysis of research decision support systems for determining the promotion of position, The author uses 4 samples taken from the number of employees per team at PT.Gramedia Asri Media, the authors conducted an analysis of the aspects of the employee profile and the criteria required for promotion at PT. GRAMEDIA ASRI. This activity is carried out in order to obtain accurate data. For promotion at PT. GRAMEDIA ASRI, aspects that have been determined as conditions for determining promotion are required. The following is a table of the aspects which are the requirements obtained from research at PT. GRAMEDIA ASRI:

Table 2

Table of Assessment Criteria

\begin{tabular}{ccl}
\hline \hline Number & Variable & \multicolumn{1}{c}{ Indicator } \\
\hline & & Sales (according to target area) \\
& Operating Income according to the unit budget \\
& A. EMPLOYEE & Survey Customer Satisfaction Index \\
PERFORMANCE & PLAN \& & $\begin{array}{l}\text { Sales Through Rate for Book }(\%) \\
\text { Average productivity of the selling room (Sales / selling } \\
\text { area / month) } \\
\text { REALIZATION }\end{array}$ \\
& Follow Up Stock Minus \\
& Develop Employee by L as T (Leader Trainer) Realization
\end{tabular}




\section{Develop Employee by IDP(Individual Development Plan) Realization \\ The amount of improvement in one period \\ Caring \\ 2 B. CONDUCT \\ Credible \\ ASPECT Competent \\ Competitive}

In Table 2, the aspects that become the requirements are obtained from research at PT.GRAMEDIA ASRI MEDIA which is the company's standard reference.

\section{RESULT}

The following are the calculation steps using the profile matching method used by the author to determine the promotion at PT. GRAMEDIA ASRI.

\section{Assessment of Employee Profile Gap Assessment of Performance Aspects and Attitude Aspects}

Table 3

Employee Profile Gap in Performance Aspects and Attitude Aspects

\begin{tabular}{|c|c|c|c|c|c|c|c|c|c|c|c|c|c|c|c|}
\hline \multirow{2}{*}{ NIK } & \multirow{2}{*}{ NAME } & \multicolumn{9}{|c|}{ Attitude Aspects } & \multicolumn{5}{|c|}{ Performance Aspects } \\
\hline & & $\mathrm{A} 1$ & $\mathrm{~A} 2$ & A3 & A4 & A5 & A6 & A7 & A8 & A9 & B1 & $\mathrm{B} 2$ & B3 & B4 & B5 \\
\hline 042039 & Ariz & 3 & 3 & 3 & 3 & 4 & 4 & 1 & 1 & 1 & 6 & 6 & 6 & 3 & 3 \\
\hline 001461 & Widi & 3 & 3 & 3 & 3 & 4 & 4 & 1 & 1 & 1 & 6 & 6 & 6 & 3 & 3 \\
\hline 042778 & nadire & 2 & 3 & 3 & 3 & 4 & 4 & 1 & 1 & 1 & 6 & 6 & 7 & 3 & 3 \\
\hline 029034 & Dikna & 1 & 3 & 3 & 3 & 4 & 4 & 1 & 1 & 1 & 6 & 6 & 6 & 4 & 4 \\
\hline Position Profile & & 5 & 5 & 4 & 5 & 5 & 4 & 3 & 3 & 3 & 5 & 4 & 4 & 3 & 5 \\
\hline 042039 & Ariz & -2 & -2 & -1 & -1 & 0 & 0 & -3 & -2 & -2 & 1 & 2 & 2 & 0 & -2 \\
\hline 001461 & Widi & -2 & -3 & -1 & -1 & 0 & 0 & -3 & -2 & -2 & 1 & 2 & 2 & 0 & -2 \\
\hline 042778 & nadire & -3 & -2 & -1 & -1 & 0 & 0 & -3 & -2 & -2 & 1 & 2 & 3 & 0 & -2 \\
\hline 029034 & Dikna & -4 & -2 & -1 & -1 & 0 & 0 & -3 & -2 & -2 & 1 & 2 & 2 & 1 & -1 \\
\hline
\end{tabular}

In table 3, the authors get the results of employee data based on the assessment of the employee profile gap in performance aspects and attitude aspects at PT. GRAMEDIA ASRI.

\section{Assessment of Weighting Gap Value for Performance Aspects and Attitude Aspects.}

Table 4

The weighted value of the Gap value of Attitude and Performance Aspects

\begin{tabular}{|c|c|c|c|c|c|c|c|c|c|c|c|c|c|c|c|}
\hline \multirow{2}{*}{ NIK } & \multirow{2}{*}{ Name } & \multicolumn{9}{|c|}{ Attitude aspects } & \multicolumn{5}{|c|}{ Performance Aspects } \\
\hline & & A1 & $\mathrm{A} 2$ & $\mathrm{~A} 3$ & A4 & A5 & A6 & A7 & A8 & A9 & $\mathrm{B} 1$ & $\mathrm{~B} 2$ & B3 & $\mathrm{B} 4$ & B5 \\
\hline 042039 & Ariz & 3 & 3 & 4 & 4 & 5 & 5 & 2 & 3 & 3 & 4,5 & 3,5 & 3,5 & 5 & 3 \\
\hline 001461 & Widi & 3 & 3 & 4 & 4 & 5 & 5 & 2 & 3 & 3 & 4,5 & 3,5 & 3,5 & 5 & 3 \\
\hline 042778 & nadire & 2 & 3 & 4 & 4 & 5 & 5 & 2 & 3 & 3 & 4,5 & 3,5 & 3,5 & 5 & 3 \\
\hline 029034 & Dikna & 1 & 3 & 4 & 4 & 5 & 5 & 2 & 3 & 3 & 4,5 & 3,5 & 3,5 & 4,5 & 4 \\
\hline
\end{tabular}

In Table 4, after getting the Gap value for each employee, which is obtained from the difference between the employee profile and the position profile with the results of the Gap value. 


\section{Calculation and Grouping of Core Factors and Secondary Factors}

Aspect Criteria that are included in the core factor group in the performance aspect are the performance aspect question 1 (A1), the performance aspect question 2 (A2), the performance aspect question 4 (A4), the performance aspect question 5 (A5). determine promotion at PT. GRAMEDIA ASRI, can be seen in Equation 6:

$N C F=\frac{E N C(A 1+A 2+A 4+A 5)}{\Sigma / C}$

Criteria aspects that are included in the secondary factor group in the attitude aspect are questions for Attitude 1 (B1), Attitude 2 (B2), and Attitude 4 (B4) aspects. can be seen in Equation 7:

$N C F=\frac{E N C(B 1+B 2+B 4)}{\Sigma / C}$.

Table 5

Core Factor and Secondary Factor Calculation Results

Performance Aspects

\begin{tabular}{clcc}
\hline \hline NIK & NAME & CORE FACTOR & SECONDARY FACTOR \\
\hline 042039 & Ariz & 7,5 & 3,4 \\
001461 & Widi & 7,5 & 3,4 \\
042778 & nadire & 7 & 3,4 \\
029034 & Dikna & 6,5 & 3,4 \\
\hline
\end{tabular}

In Table 5, the criteria aspects that fall into the core factor group in the Attitude aspect are the Attitude Aspect Question 1 (B1) and the Attitude Aspect Question 5 (B5). The formula of the Core Factor on the attitude aspect for determining the Promotion of Solid Position of PT. Gramedia Asri Media, can be seen in Equation 8:

$$
N C F=\frac{E N C(B 1+B 5)}{\Sigma / C}
$$

Aspects of the criteria included in the secondary factor group in the attitude aspect are questions for Attitude 1 (B1), Attitude 2 (B2), and Attitude 4 (B4) aspects., can be seen in Equation 9:

$$
N C F=\frac{E N C(B 1+B 2+B 4)}{\Sigma / C}
$$

Table 6

Core Factor and Secondary Calculation Results

\begin{tabular}{|c|c|c|c|}
\hline NIK & NAME & $\begin{array}{c}\text { CORE } \\
\text { FACTOR } \\
\end{array}$ & SECONDARY FACTOR \\
\hline 042039 & Ariz & 3,25 & 4,333 \\
\hline 001461 & Widi & 3,25 & 4,333 \\
\hline 042778 & nadire & 2,75 & 4,333 \\
\hline 029034 & Dikna & 3,75 & 4,167 \\
\hline
\end{tabular}
Attitude aspect factors

In Table 6, the results of the calculation of the Core factor and Secondary Factor in the attitude aspect are the results of the employees shown in the table.

c. Calculation of the Total Value of Performance Aspects and Attitude Aspects

Calculation of the Total Value of Performance Aspects, with the following details

Total Performance Score $=(80 \%$ x 7,500$)+(20 \% \times 3,400)$

$$
\begin{aligned}
& =6,000+0,6800 \\
& =6,6800
\end{aligned}
$$

$80 \%$ is obtained from multiplying the percentage of the number of Core Factors in the performance aspect, which consists of 4 sub aspects (A1, A2, A4, A5) of 9 sub aspects in the performance aspect. While $20 \%$ is obtained from multiplying the percentage of the number of Secondary Factors in the performance aspect which consists of 5 (A3, A6, A7, A8, A9) from 8 sub aspects of performance aspects. Following are the results of the calculation of the total value of the academic aspects of all Prospective Students for the Determination of Promotion at PT. Gramedia Asri Media.

Table 7

The Result of Calculating the Total Value of Performance Aspects 


\begin{tabular}{ccccc}
\hline \hline NIK & NAME & $\begin{array}{c}\text { CORE } \\
\text { FACTOR }\end{array}$ & $\begin{array}{c}\text { SECONDARY } \\
\text { FACTOR }\end{array}$ & TOTAL \\
\hline 042039 & Ariz & 6,00 & 0,6800 & 0,6800 \\
001461 & Widi & 6,00 & 0,6800 & 0,6800 \\
042778 & nadire & 5,600 & 0,6800 & 6,2800 \\
029034 & Dikna & 5,200 & 0,6800 & 5,8800 \\
\hline
\end{tabular}

In Table 7, the calculation results of the Core factor and Secondary Factor in the attitude aspect are the results of the employees shown in the table.

Calculation of the Total Value of Attitude Aspects, with the following details :

Total Attitude Score $=(75 \%$ x 3,2500 $)+(25 \%$ x 4,3333)

$$
\begin{aligned}
& =2,4375+1,0833 \\
& =3,5208
\end{aligned}
$$

$75 \%$ is obtained from the result of multiplying the percentage of the number of Core Factors in the attitude aspect, which consists of 2 sub-aspects (B3, B5) of 3 sub-aspects in the attitude aspect. While $25 \%$ is obtained from multiplying the percentage of the number of Secondary Factors in the attitude aspect, which consists of 3 sub-aspects (B1, B2, B4) of the 5 sub-aspects that exist in the attitude aspect. The following is the calculation result of the total value of the attitude aspects of all candidates for determining the Promotion of Solid Position of PT.Gramedia Asri Media.

\section{Ranking Determination Calculations}

The final result of the profile matching process is the ranking of candidates submitted for promotion. Determination of the ranking refers to the results of certain calculations. This calculation can be shown by the following formula:

$$
\text { Rank }=(60 \% \text { xA })+(40 \% x \mathrm{NB})
$$

\begin{tabular}{cllll}
\multicolumn{5}{c}{$\begin{array}{c}\text { Table } 8 \\
\text { Ranking }\end{array}$} \\
\hline \hline NIK & NAME & PERFORMANCE & ATTITUDE & TOTAL RANK \\
\hline 042039 & Ariz & 4,008 & 1,4083 & 5,4163 \\
001461 & Widi & 4,008 & 1,4083 & 5,4163 \\
042778 & nadire & 3,768 & 1,2583 & 5,0263 \\
029034 & Dikna & 3,528 & 1,5417 & 5,0697 \\
\hline
\end{tabular}

In Table 8, the results of the ranking determination calculation, for the promotion of elected 2 employees Ariz and Widi.

\section{DISCUSSIONS}

Based on the results of the research that has been submitted, PT.Gramedia Asri Media can make a promotion by applying the Profile Matching method as a result of research that has proven its accuracy. In this research, using the Profile Mtatching method only uses 2 criteria to determine the best employee for promotion. The selection of assessment criteria and variables and the determination of standard values for each personnel profile is very influential in the process of appointment. The search for core factor and secondary factor values is searched using the Profile Matching method. Matching has a difference of 63\%.Based on the research results that have been submitted to PT. Gramedia Asri Media, can be promoted by applying the Profile Matching method as a result of research that has proven its accuracy. Thus, those who are entitled to promotion of employees named Ariz and Widi get the highest final score of 5.4163 and are ranked 1 (I) out of 4 employees recommended for promotion at the company.

\section{CONCLUSION}

Decision support system application that applies the Profile Matching method to facilitate decision making for the best employees to get promotion promotions. This system is only a tool for decision making, the final decision remains in the hands of the decision maker. With the calculations that have been done with the Profile Matching method, starting with the weighting of the criteria, then the calculation and grouping of cores and secondary factors, calculating the total and then calculating the determination of ranking. Based on the research results that have been submitted to PT. Gramedia Asri MediaI, may be promoted by applying the Profile Matching method as a result of research that has proven its accuracy. Thus, those who are entitled to promotion of employees named Ariz and Widi who get the highest final score, namely 5.4163 and are in the 1st (First) rank of 4 employees recommended for promotion at the company. 


\section{REFERENCES}

Abdullah, D., Djanggih, H., Suendri, S., Cipta, H., \& Nofriadi, N. (2018). Fuzzy model tahani as decision support system for employee promotion. International Journal of Engineering and Technology(UAE), 7(2.5 Special Issue 5), 88-91. https://doi.org/10.14419/ijet.v7i2.5.13958

Adianto, T. R., Arifin, Z., Khairina, D. M., Mahakam, G., \& Palm, G. (2017). Decision Support System for Choosing Residential Houses in Residential Using the Simple Additive Weighting (Saw) Method (Case Study: Samarinda City). Prosiding Seminar Ilmu Komputer Dan Teknologi Informasi, 2(1), 197-201.

Akhirina, T. Y. (2016). Simple Additive Weighting Method Comparison and Profile Matching on Selection of Freight Forwarding Service Partners. Jurnal Edukasi Dan Penelitian Informatika (JEPIN), 2(1), $27-33$. https://doi.org/10.26418/jp.v2i1.15500

Antonius, B., \& Widjaja, A. (2019). Application of Decision Support System for Promotion of Position at PT. World Infinite Network with Profile Matching Method. Jurnal IDEALIS, 2(2), 257-264.

Ariyanto, F., \& Muslihudin, M. (2015). Decision Support System to Determine the Leading Vocational High School (Smk) in the Central Lampung Region Using the Topsis Method. Jurnal TAM (Technology Acceptance Model), 5, 1-8.

Fitri, N. Y. (2017). Analysis and Design of a Decision Support System for Teacher Performance Appraisal Using the Simple Additive Weighting (Saw) Method at Yadika Junior High School Jambi. Manajemen Sistem Informasi, 2(1), 318-326.

Junaidi, A., \& Visella, F. (2017). Selection of Scholarship Recipients Using the Profile Matching Method. Paradigma, 19(2).

Kay, D., \& Kibble, J. (2016). Learning theories 101: Application to everyday teaching and scholarship. Advances in Physiology Education, 40(1), 17-25. https://doi.org/10.1152/advan.00132.2015

Nisa, K., \& Sutinah, E. (2018). Profile Matching for Decision Support Systems for Selection of Maintenance Server and Network Vendors. Jurnal Informatika, 5(2), 262-269. https://doi.org/10.31311/ji.v5i2.3638

Nur Aziz Sugiharto. (2016). Analysis of the Implementation of PSAK no.45 concerning Financial Reporting of Non-Profit Entities for Educational Foundations (Case Study at Yyasan Pendidikan Bhakti Pos Indonesia). COMPETITIVE, 11(2).

Pradnyawati, G. A. K., \& Komalasari, Y. (2017). Effect Of work Achievement And Employee Training On Career Development At a Dhijaya Hotel Kuta-Bali. Manajemen, 13(1), 177-188.

Sahya Anggara. (2016). State Civil Service Administration. CV PUSTAKA SETIA, 1-339.

Sofiati, Y. S. A. A. (2018). Human Resource Management: Indirect and Environmental Compensation. Retrieved from

https://books.google.co.id/books?id=ahx5DwAAQBAJ\&dq=Dari+jumlah+tersebut+perusahaan+akan+me nilai+karyawan+yang+akan+dipromosikan+di+perusahaan,+dengan+syarat+semua+penilaian+termasuk+d alam+kategori+Meet+Expectation+jika+tidak+mencapai+Meet+Expectation,+maka+karyawan+tersebut+t idak+dapat+mengikuti+tes+promos\&lr=\&hl=id\&source=gbs_navlinks_s

Susan, E. (2019). Human Resource Management. Jurnal Manajemen Pendidikan, (2), 952-962.

Susanti, T. R. I. (2020). Analysis of the Effect of Health, Education, Asset Ownership on Household Poverty in an Islamic Economic Perspective. Skripsi Repository. Retrieved from http://repository.radenintan.ac.id/9728/1/skripsi bab 1\%262.pdf

Susanto, H. (2018). Application of the Additive Ratio Assessment (Level) Method in Supporting the Decision to Choose the Best Gym Milk to Increase Muscle Mass. Majalah Ilmiah INTI, 13, 1-5.

Tinggiana, Y., Pujiastuti, A., D. (2018). Learning Handbooks based on Higher-Order Thinking Skills. 1-86.

Tremblay, J., Prakash, A., Acuna, D., Brophy, M., Jampani, V., Anil, C., ... Birchfield, S. (2018). Training deep networks with synthetic data: Bridging the reality gap by domain randomization. IEEE Computer Society Conference on Computer Vision and Pattern Recognition Workshops, 2018-June, 1082-1090. https://doi.org/10.1109/CVPRW.2018.00143

Wati, R., \& Mayasari, E. (2015). Decision Support System for Selection of Superior Cattle Seeds with the Simple Additive Weighting (SAW) Method at Sriagung Cattle Farm, Padangratu, Central Lampung. Jurnal TAM (Technology Acceptance Model), 5, 22-28.

Wong, C. S., \& Law, K. S. (2017). The effects of leader and follower emotional intelligence on performance and attitude: An exploratory study. In Leadership Perspectives (Vol. 13). https://doi.org/10.4324/9781315250601-10 